\title{
SOIL, WATER AND LAND USE: \\ II. Understanding Nitrogen Interactions
}

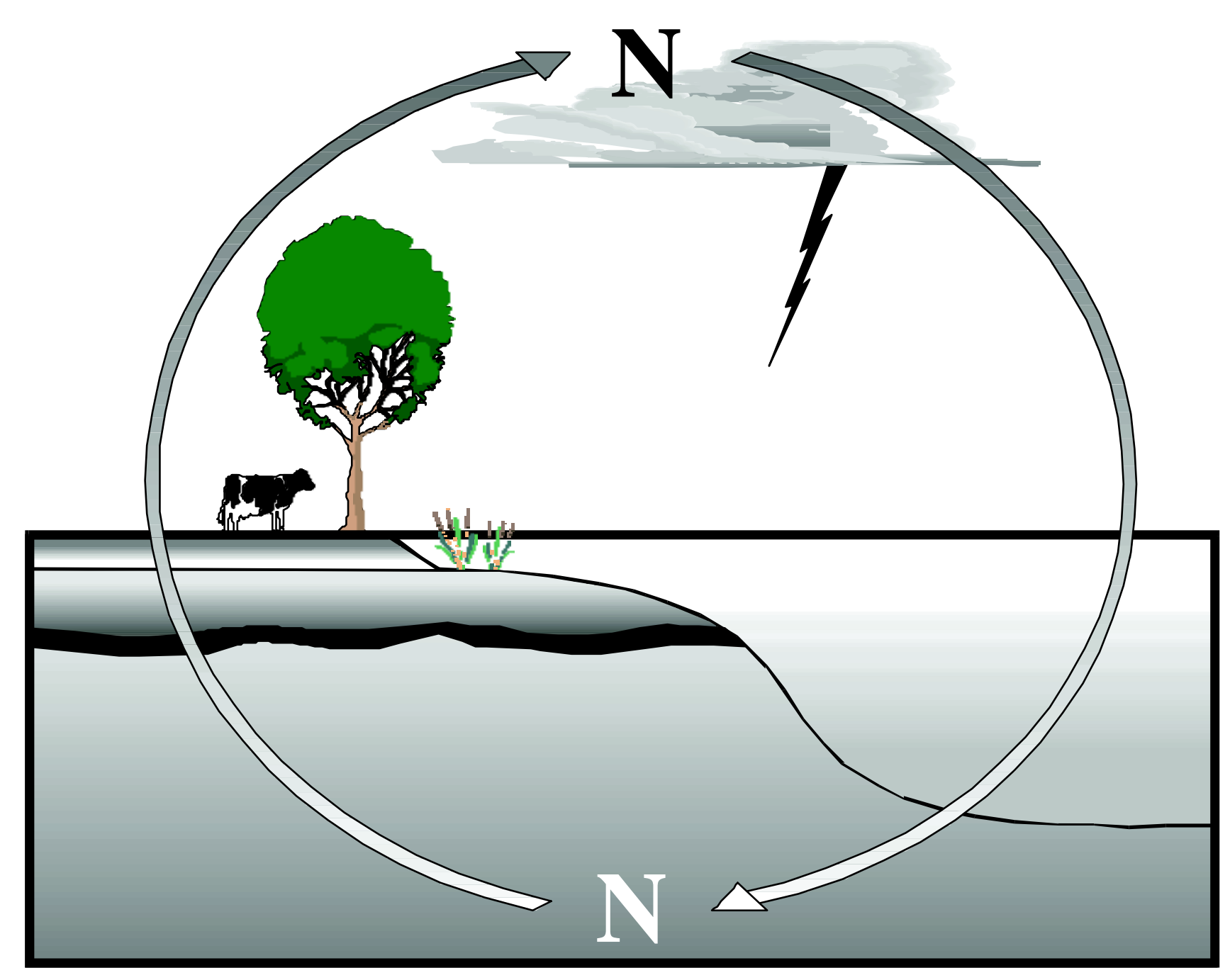

A Soil and Water Education Project Kit

For Ages 15-18
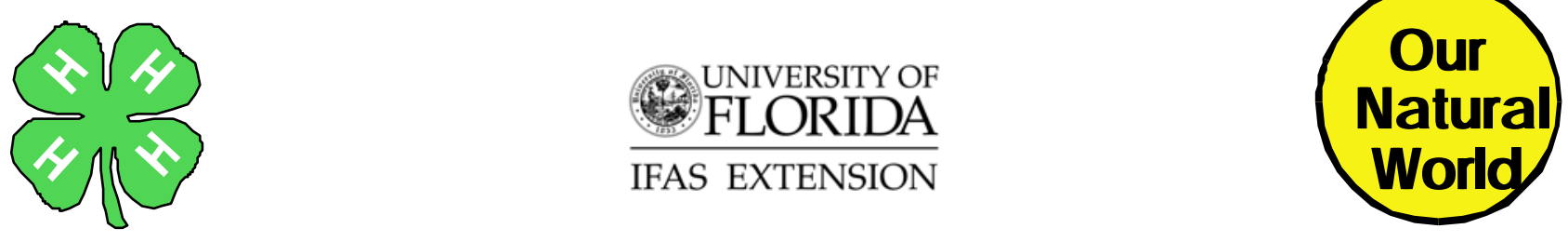


\section{SOIL, WATER AND LAND USE}

\section{Understanding Nitrogen Interaction}

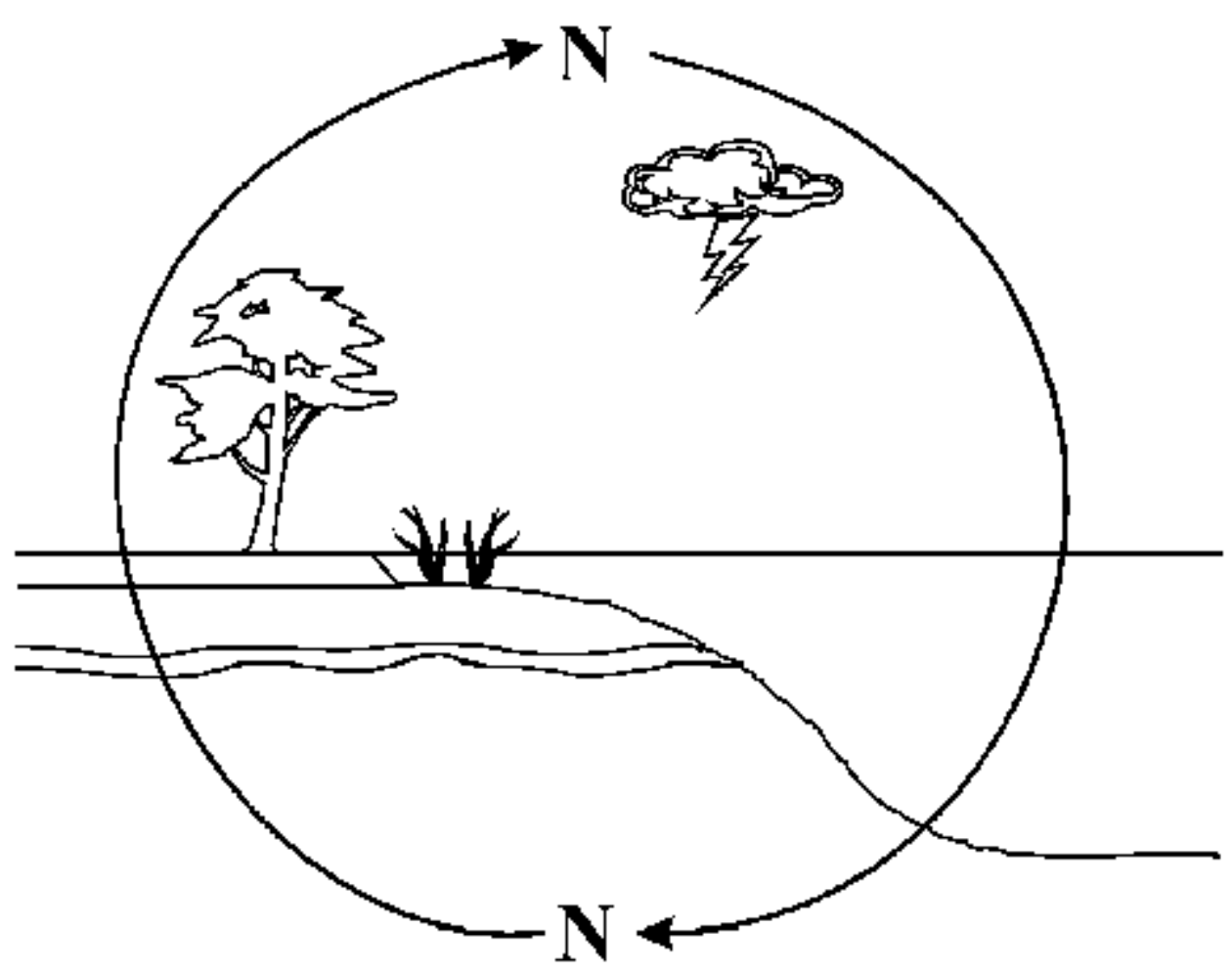

\section{A Soil and Water Education Project Kit}

Produced jointly by the Soil and Water Science Departinent and the Deparment of $4-\mathrm{H}$ and Other Youth Programs, Florida Cooperative Extension Service, Institute of Food and Agricultural Sciences. Unıersity of Florida. September 1993. Reviewed June, 2002.

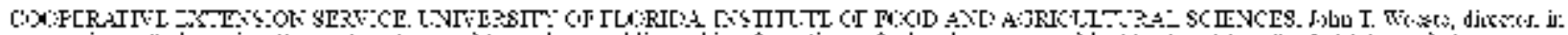

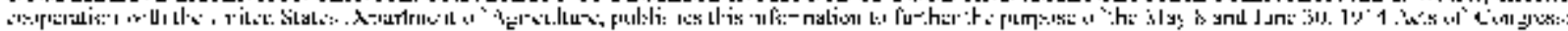

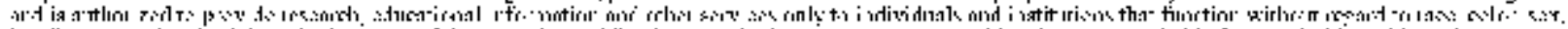

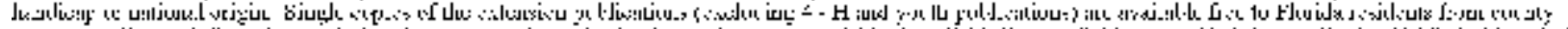

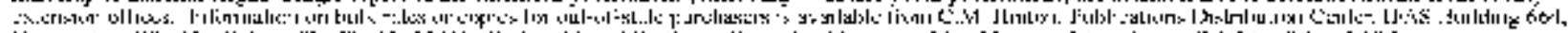

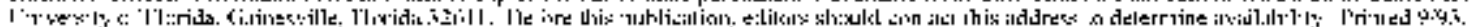




\section{SOIL, WATER AND LAND USE:}

\section{Understanding Nitrogen Interactions}

A Soil and Water Education Project Kit

Soil, Water and Land Use: II. Understanding Nitrogen Interactions was written by Angela Schipper, Louis Schipper and Art Hornsby of the Soil and Water Science Department, University of Florida.

Figures and other graphics were produced by Alison Edgell.

Special thanks for technical review and assistance to Randy Brown, Paula Gale, Ed Hanlon, and Jerry Kidder, Soil and Water Science Department, University of Florida.

This project was supported by USDA-ES Smith Lever 3(d), Water Quality Initiative Program support funds.

For information on ordering a copy of Soil, Water and Land Use: II. Understanding Nitrogen Interactions contact:

IFAS Publications Distribution Center

P.O. Box 110011

Gainesville, FL 32611

Phone: (904) 392-1764 


\section{PREFACE}

Nitrogen is an essential element that all living things require for life and growth. However, nitrogen can also be a source of concern. Forms of nitrogen have been linked to potentially harmful effects on human and animal health, and the environment. The goal of Soil, Water and Land Use: II. Understanding Nitrogen Interactions is to increase the understanding of nitrogen, its importance to life and its implications for water quality. Once students realize the interrelationship between individual actions and environmental effects, these same students can make more responsible and informed decisions about our natural resources.

The learning activities in this project use simple, inexpensive materials. The activities lend themselves to group work and participant-led discussions and conclusions to support the given background material. These activities follow the belief that learning should be a combination of discovery, discussion and learning from those who are more knowledgeable.

Although designed for high-school students, this curriculum package could be used in lower grades. Background knowledge varies with the age and experience of the students involved. Therefore, teachers are encouraged to choose activities most appropriate to classroom needs and time limitations.

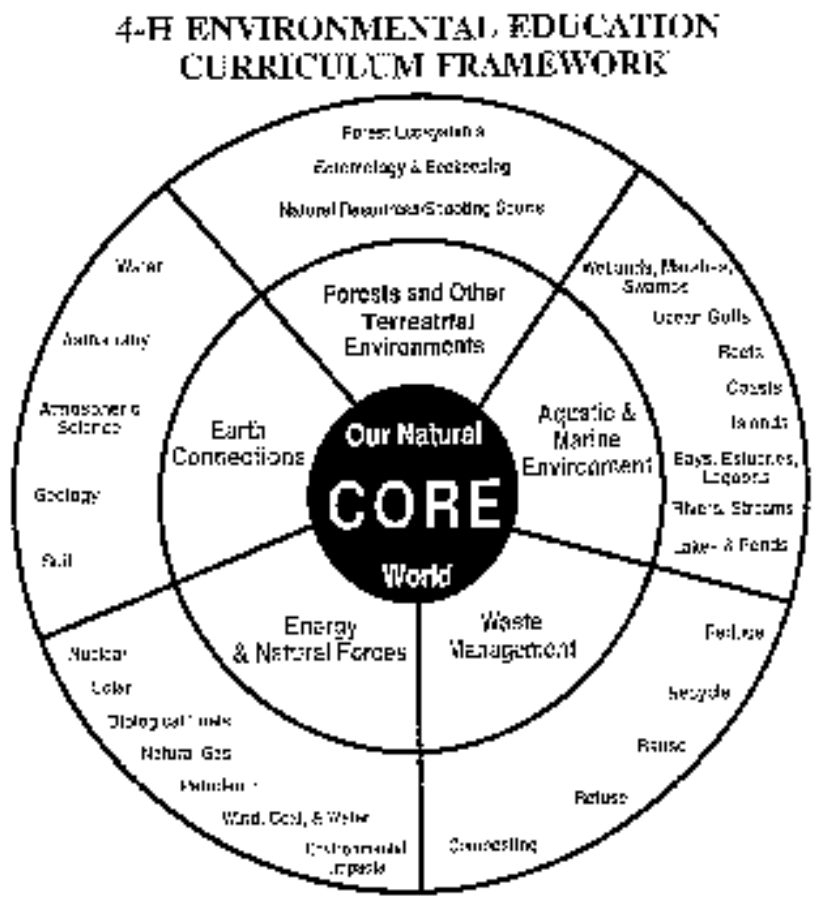




\section{TABLE OF CONTENTS}

\section{INTRODUCTION}

Credits ....................................... ii

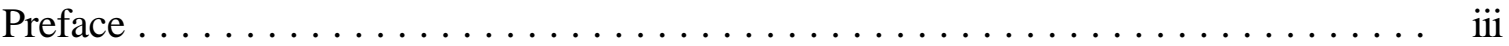

Table of Contents ... . . . . . . . . . . . . . . . . . .

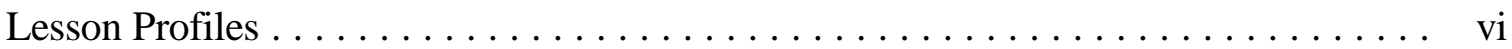

Estimated Length of Activities $\ldots \ldots \ldots \ldots \ldots \ldots \ldots \ldots \ldots \ldots \ldots \ldots \ldots$ vii

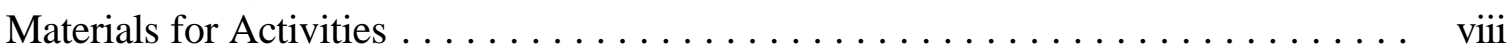

Experiential Process Techniques . . . . . . . . . . . . . . . . . . . .

Experiential Learning Model $\ldots \ldots \ldots \ldots \ldots \ldots \ldots \ldots \ldots \ldots \ldots \ldots \ldots \ldots \ldots \ldots \ldots \ldots$

II SOIL, WATER AND LAND USE: II. Understanding Nitrogen Interaction

LESSON 1: Nitrogen - An Essential Element $\ldots \ldots \ldots \ldots \ldots \ldots \ldots \ldots \ldots \ldots \ldots$

Activities

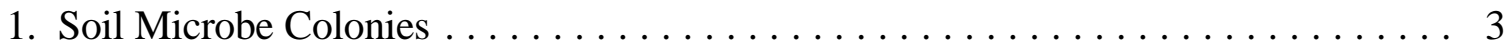

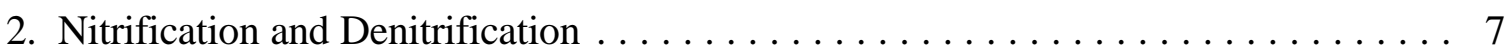

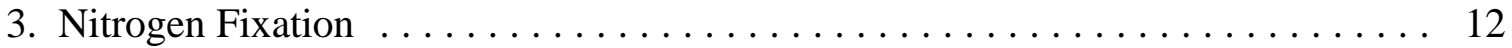

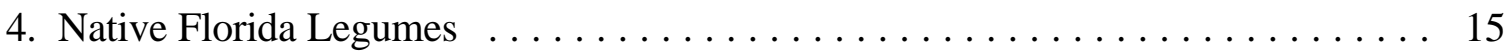

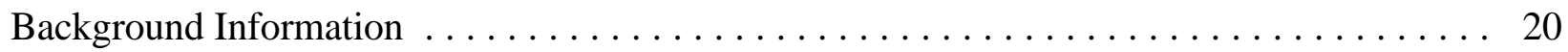

LESSON 2: Environmental and Health Concerns $\ldots \ldots \ldots \ldots \ldots \ldots \ldots \ldots \ldots \ldots$

Activities

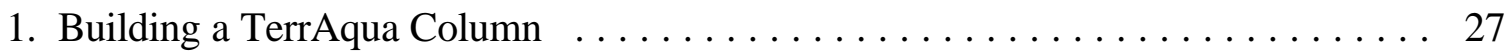

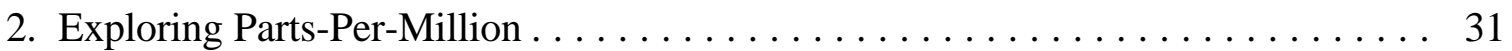

3. Testing Water For Nitrate $\ldots \ldots \ldots \ldots \ldots \ldots \ldots \ldots \ldots \ldots \ldots \ldots \ldots \ldots \ldots \ldots \ldots \ldots$

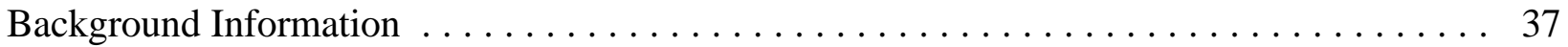

LESSON 3: Nitrogen Considerations in Natural Systems $\ldots \ldots \ldots \ldots \ldots \ldots \ldots \ldots . \ldots$

Activities

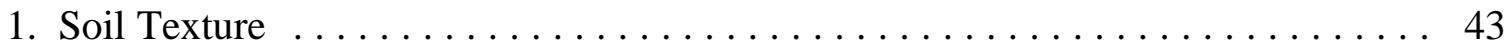

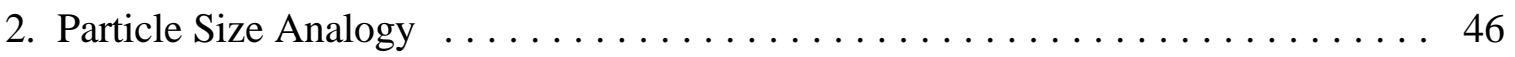

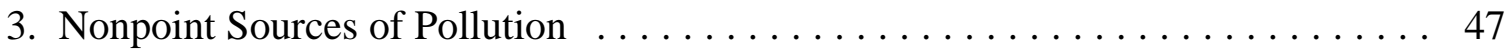

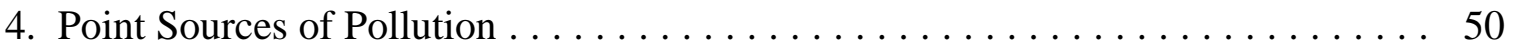

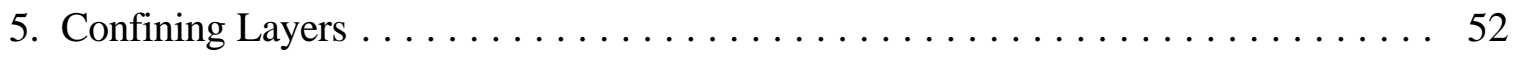

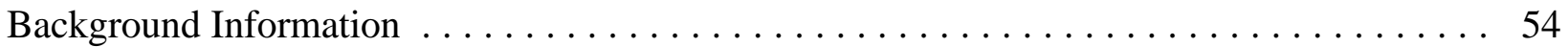




\section{TABLE OF CONTENTS}

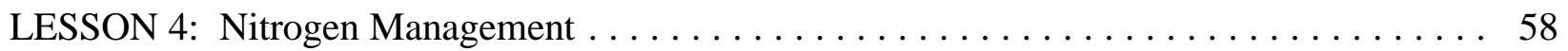

Activities

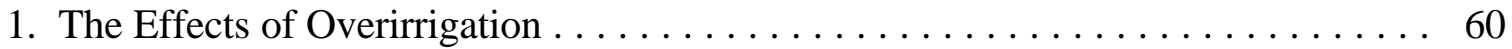

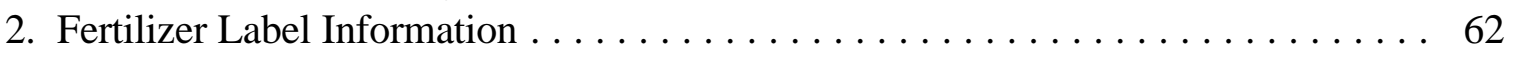

3. Determining the Nitrogen Content of Fertilizers $\ldots \ldots \ldots \ldots \ldots \ldots \ldots \ldots$

4. Fertilizer "Spreadsheet" . . . . . . . . . . . . . . . . . . . . . . . . . . 69

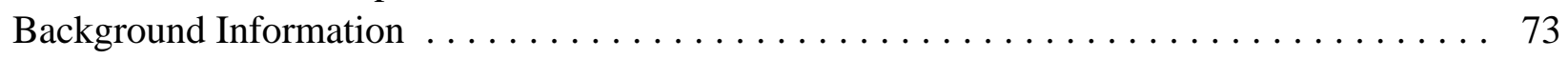

LESSON 5: Alternative Nitrogen Sources $\ldots \ldots \ldots \ldots \ldots \ldots \ldots \ldots \ldots$

Activities

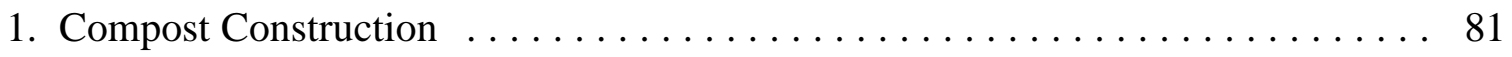

2. Determining the Amount of Nitrogen in Compost $\ldots \ldots \ldots \ldots \ldots \ldots \ldots \ldots$

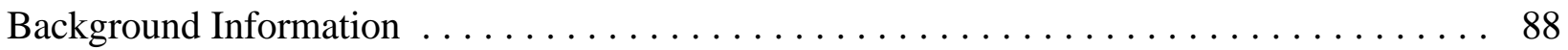

III TAKE-HOME ACTIVITIES

\#1 Drinking Water Origins - Municipal $\ldots \ldots \ldots \ldots \ldots \ldots \ldots \ldots \ldots \ldots \ldots \ldots \ldots \ldots$

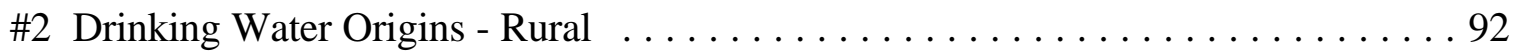

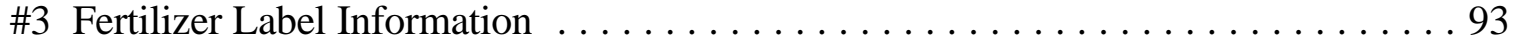

\#4 Fertilizer Scavenger Hunt . . . . . . . . . . . . . . . . . . . . . 94

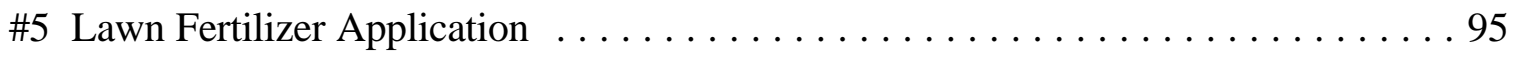

IV SUPPLEMENTAL MATERIALS

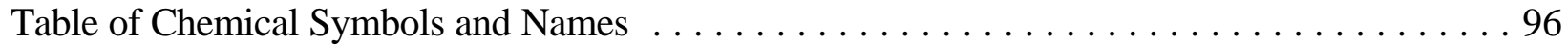

Nitrogen Reactions in Soil . . . . . . . . . . . . . . . . . . . . . . . 97

Recommendations for Nitrate-Nitrite in Public Water Supplies . . . . . . . . . . . . . . 99

Legumes Native or Naturalized in Florida . . . . . . . . . . . . . . . . . . . . . . 102

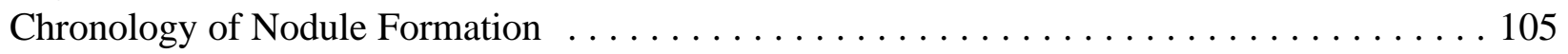

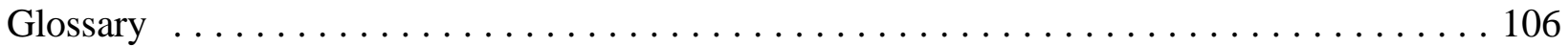

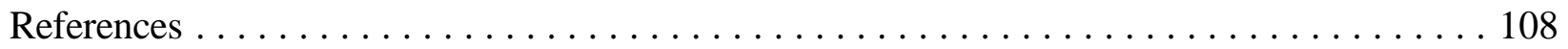

V EVALUATION

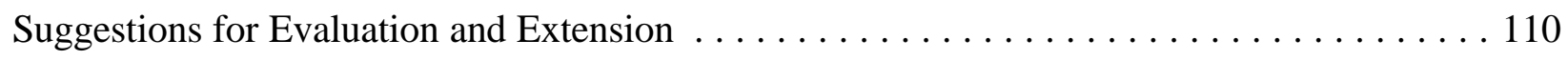

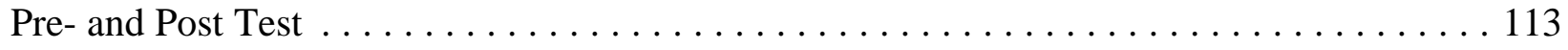




\section{LESSON PROFILES}

\section{Lesson 1: Nitrogen- An Essential Element}

Lesson 1 emphasizes the importance of nitrogen to human, animal and plant life. The background information explains the chemical and biological transformations of the nitrogen cycle. Activities focus upon soil microbes, nitrification, denitrification and nitrogen fixation.

\section{Lesson 2: Environmental and Health Concerns}

This lesson covers the effects of nitrate on human and animal health along with some environmental consequences of excess nitrogen in aquatic ecosystems. Activities provide a visual understanding of surface water degradation and chemical concentration (parts-per-million). Students can learn how to test water for nitrate.

\section{Lesson 3: Nitrogen Considerations in Natural Systems}

Students learn how soil properties and the makeup of aquifers affect movement of nitrate in the environment. Activities demonstrate the effect of soil texture on water infiltration, show how point- and non-point pollution sources enter into ground and surface water, and illustrate how confining layers can protect aquifers from contamination.

\section{Lesson 4: Nitrogen Management}

Students learn about a number of factors that should be considered for nitrogen management in agricultural and urban settings. Activities focus on understanding practical fertilizer matters including overirrigation, fertilizer-product labels and the nitrogen content of commercial fertilizers.

\section{Lesson 5: Alternative Nitrogen Sources}

This lesson introduces students to alternatives to commercial fertilizers through reuse of organic waste products. The background information explains the composting process and the nitrogen content of various composted materials. Students learn the composting process by developing their own compost pile. 